Article

\title{
Social Media, Populism, and Migration
}

\author{
Mario Datts \\ Submitted: 30 April 2020 | Accepted: 19 June 2020 | Published: 8 October 2020
}

Institute of Social Sciences, University of Hildesheim, 31141 Hildesheim, Germany; E-Mail: mario.datts@uni-hildesheim.de

\begin{abstract}
Several scholars have attributed high hopes to social media regarding their alleged ability to enable a nonhierarchical and freely accessible debate among the citizenship (Loader \& Mercea, 2011; Shirky, 2011). Those hopes have culminated in theses such those describing the social web as being a 'new public sphere' (Castells, 2009, p. 125) as well as in expectations regarding its revitalizing potential for the 'Habermas's public sphere' (Kruse, Norris, \& Flinchum, 2018, p. 62). Yet, these assumptions are not uncontested, particularly in the light of socially mediated populism (Mazzoleni \& Bracciale, 2018). Interestingly, research on populism in the social web is still an exception. The same is true for the populist permeation of the social media discourse on migration, as a highly topical issue. This study seeks to elaborate on this research gap by examining to what extent the Twitter debate on the Global Compact for Safe, Orderly, and Regular Migration (GCM) was permeated by populist content. For this purpose, almost 70,000 tweets on the most important Hashtags referring to the GCM that took place in Marrakesh in December 2018 were collected and the 500 widest-reaching tweets analysed in terms of their populist permeation. Against initial expectations, the empirical findings show that populist narratives did not dominate the Twitter debate on migration. However, the empirical results indicate that ordinary citizens play an important role in the creation and dissemination of populist content. It seems that the social web widens the public sphere, including those actors who do not communicate in accordance with the Habermasian conceptualization of it.
\end{abstract}

\section{Keywords}

migration; populism; social media; Twitter

\section{Issue}

This article is part of the issue "The Ongoing Transformation of the Digital Public Sphere" edited by Emiliana De Blasio (LUISS University, Italy), Marianne Kneuer (Hildesheim University, Germany), Wolf J. Schünemann (Hildesheim University, Germany) and Michele Sorice (LUISS University, Italy).

(C) 2020 by the author; licensee Cogitatio (Lisbon, Portugal). This article is licensed under a Creative Commons Attribution 4.0 International License (CC BY).

\section{Introduction}

It is widely assumed that social media has become an integral part of the public sphere (Castells, 2009; Papacharissi, 2009; Shirky, 2011). Castells (2009, p. 125), as one of the most prominent proponents of a network society, even speaks of the emergence of a 'new public sphere.' However, there are also critical voices (Kruse, Norris, \& Flinchum, 2018) stating that citizens do not engage on social media in a way that matches the wellknown criteria from the concept of 'communicative rationality' as established by Habermas $(1984,1989)$. Already in the late 1990s and early 2000s, researchers were able to demonstrate that illiberal voices were more visible on the Internet than liberal ones (Hill \& Hughes, 1998, p. 153) and hypothesized that the "growth of vir- tual counter-public spheres" (Downey \& Fenton, 2003, p. 199) would lead to an increasing impact of rightist actors on the public debate. This article intends to contribute to the long-running discussion on the influence of digital media on the public sphere by analysing the populist permeation of social media discourse on migration. The focus on populism and migration seems reasonable since populist communication strategies have to be seen as the exact opposite of the Habermasian ideal of communicative rationality and thus as a challenge for the public sphere (Privitera, 2018). The populist challenge is especially noticeable in the public debate on migration, which has recently become a major issue (Heidenreich, Eberl, Lind, \& Boomgaarden, 2020, p. 1261). While there are studies on the degree of populist pervasion of mass media (Rooduijn, 2014), as well as on the mass media 
coverage of migration (Eberl et al., 2018) and the social media discourse on migration (Heidenreich et al., 2020), no research concerning social media, populism, and migration has been conducted so far.

The main empirical objective of this article is to form a better understand the characteristic of the populist discourse concerning migration on social media. For the purpose of this article, the global Twitter discourse on the intergovernmental signing conference of the Global Compact for Safe, Orderly, and Regular Migration (GCM) in Marrakesh in December 2018 will be examined. This study will focus on Twitter due to its significance for the agendas of the mass media and thereby for the wider perception of political issues. It has been shown that mainstream news media frequently respond to trending topics on Twitter (Araujo \& van der Meer, 2020, p. 634), which can be observed especially well concerning the mass media coverage of tweets by the US American President Donald Trump (Fuchs, 2017, pp. 53-54). The usage of Twitter as a source for news media is very common among journalists. One might even speak of "a reversed agenda-setting pattern" (Araujo \& van der Meer, 2020, p. 647). Thus, debates on Twitter influence the public debate outside the Twitter realm.

The following questions will guide the investigation: (RQ1) how strongly was the Twitter discourse on migration permeated with populist content during the signing conference on the GCM? Since this article deals with migration, in other words, with the core issue of rightwing populist actors (Jagers \& Walgraave, 2007, p. 322; Lutz, 2018, p. 517), this article is especially interested in the number of right-wing populist tweets. If it emerges that there were (right-wing) populist tweets, the following question arise: (RQ2) which populist communication strategies were employed? Thus, this study sheds light on the degree of populist content in the online discourse regarding migration (content dimension: What is published?) and about populist communication strategies (strategic dimension: How is populist content published?). It needs to be stressed that this article is not solely interested in social media activities of political actors who are well-known for their populist attitude, but also in those of 'ordinary' citizens since their populist activities also have to be examined if one wants to fully understand populism on social media. Moreover, the concept of the public sphere requires the "equal and protected participation" (Kruse et al., 2018, p. 63) in public debates. Since social media is credited with free access and a non-hierarchical structure of debate, it seems to match those key features of the Habermas's public sphere. Even though the focus of this article is on social media and populism, it aims to make an empirical contribution to the primarily theoretic debate on the public sphere.

In Section 2, a brief explanation of the GCM is presented. The following part of the article intends to present a conceptualisation of the term 'populism,' as well as an overview of the current state of research on populism and social media. A specific focus is placed on the role of non-elite actors in the realm of populism since this aspect has been widely neglected by academic research. Before the empirical part of the study is described in detail (Section 5), I will give an insight into the research design of this article and its methods (Section 4). The article concludes with a summary of the main findings and an indication of further aspects to be examined (Section 6).

\section{The Global Compact for Safe, Orderly, and Regular Migration}

The GCM is seen as an extremely important compact in the realm of international migration policy since it is the "first negotiated United Nations document to address migration governance comprehensively and to receive wide support" (Bloom, 2019, p. 481). The GCM is the result of a UN Resolution-the so-called New York Declaration of 2016 (United Nations Human Rights, 2016). This declaration places the GCM in the wider context of the United Nations' 2030 Agenda for Sustainable Development. The New York Declaration launches a sequence of intergovernmental consultations and negotiations towards the development of a GCM. This subsequent process concluded with the adoption of the GCM by 164 UN member states at a signing conference in Morocco. The formal endorsement by the UN General Assembly took place on December 19th (International Organisation for Migration, 2019). The agenda, as well as the compact, stresses the potential of migration for enriching the societies of the recipient countries. The main objective of the GCM is the reduction of risk and vulnerability during the migration process by establishing an international framework. The final version of the GCM includes several mentions of the state's human rights obligations concerning migrants (Guild, Basaran, \& Allinson, 2019; United Nations, 2020). The closing statement of the signing conference by Louis Arbor (Special Representative of the Secretary-General for International Migration) includes the notion that the GCM has to be seen as "a re-affirmation of the values and principles embodied in the UN Charter" and as a commitment "to safer and fairer ways of managing borders" (United Nations, 2018). Although the GCM is not legally binding, and although the principle of state sovereignty remains unaffected (Bloom, 2019, p. 482), its adoption was preceded and accompanied by an extensive and mostly adversarial debate in several countries which even lead to some governments to refuse to sign it (e.g., US, Hungary, Poland, Austria, Italy). The US government, for example, rejected signing the GCM with reference to its right to decide "how to secure its borders, and whom to admit for legal residency" (US Mission to the United Nations, 2018). Other governments made a similar argument. The potential loss of sovereignty seems to have influenced the debate, although the compact in its own right has given no cause for this fear. 


\section{Populism and Social Media}

Despite the frequently mentioned ambiguity in terms of the populism concept (Müller, 2016, p. 2), one finds central elements that have been part of most definitions of the concept. One of the oldest, though most important elements of populism, is the "reference to an analogical basis which is the people" (Laclau, 1979, p. 165). The appeal to 'the people' as a very basic aspect of populism confronts researcher with the problem that the people" "is a concept without a defined theoretical status" (Laclau, 1979, p. 165). This might be one reason for the "ambiguity surrounding 'populism"' (Laclau, 1979, p. 165). Bearing this in mind, a meaningful conceptualization of populism, as a prerequisite for a valid operationalization (see Section 4), needs additional definition criteria. Thus, almost all conceptualizations of populism contain anti-elitism as a second very basic criterion. Anti-elitism is, in the words of Canovan (1999, p. 3), "directed not just at the political and economic establishments but also opinion-formers in the academy and the media." It seems important to understand that "populism challenges not only established power-holders but also elite values" (Canovan, 1999, p. 3). Mudde (2004, p. 543) sums up the aforementioned conceptualization fragments well when he states that populism "considers society to be ultimately separated into two homogeneous and antagonistic groups" and in which the socalled pure people are exploited by a corrupt elite. Thus, populists prefer politics to be "an expression of the volonté générale (general will) of the people." The last aspect refers to the alleged goal of populists, namely to ensure that the will of the people is enacted against the resistance of the so-called elite. Analysing the recent academic debate on populism, it seems fair to conclude that the aforementioned core elements of the long-standing discussion about a useful conceptualization of the term populism-people-centrism, anti-elitism, and restoring the sovereignty of the (good) people-are more or less consensual (Meléndez \& Kaltwasser, 2019, p. 520). Those elements point out that "populist politics is not ordinary, routine politics," but politics with an "extra emotional ingredient," that "can turn politics into a campaign to save the country or to bring about a great renewal," as Canovan (1999, p. 6) put it. Right-wing populism can be understood as a specific characteristic of populism (Krämer, 2017, p. 1295). One of its special characteristics is its strong emphasis on 'the others' (Bobba, 2019, p. 16). This aspect refers to groups other than the elites who are suspected of endangering "people's values, identities and rights" (Bobba, 2019, p. 13), namely to "different ethnicities, cultures, or nations" (Krämer, 2017, p. 1296).

Most of the research on populism has been conducted in terms of traditional mass media. Academic research on populism and mass media has revealed, among other things, an "affinity between a populist communication style and 'media logic"' (Sorensen, 2018, p. 2). Interestingly the same seems to hold for populism and the logic of social media. Bartlett (2014, p. 106) considers that populist actors would profit from the prevalence of said new digital media since their inherent logic would match perfectly with their communication style. There is plenty of research on the logic of social media, from which we know that "emotional, controversial, even violent content typical of much populist activism" (Mazzoleni \& Bracciale, 2018, p. 3) is shared by users of those social networking sites much more frequently than messages with a balanced expression of opinion. This is why populist messages frequently have such a resonance on social media (Bobba, 2019, p. 11). Due to the horizontal network architecture of Twitter and other social media tools, messages can spread to huge publics: "In the context of Twitter, a handful of hops in a retweet chain is enough to reach a substantial audience and saturation is usually reached within one day" (Araujo \& van der Meer, 2020, p. 636).

As journalists are especially interested in trending topics, populist news on social media is very likely to spill over in the traditional media system and thereby extend the reach of a tweet dramatically. Moreover, populist tweets often contain a higher news value, since journalist tend to select negative and sensational content, which has been well described by the theory of news selection (Galtung \& Ruge, 1965; Lippmann, 1922; Östgaard, 1965). The key news factors, described in the theory of news values, also seem to be an important selection criterion for the public, as Araujo and van der Meer (2020, p. 637) put it with reference to Eilders (2006). Thus, populist messages on Twitter and other social media platforms are very likely to be exported and noticed beyond the boundaries of their origin (van Dijck \& Poell, 2013). Araujo and van der Meer (2020, p. 647) witness a dynamic interplay between Twitter and traditional media. The connection between traditional media and digital media was prominently described by Chadwick (2017) who named this new communication eco-system a 'hybrid media system.' Especially "'elite' populist actors" (Krämer, 2017, p. 1294), such as political parties, know about the different media logics and the connection between the traditional and the new media and apply a populist communication style, not only because it matches their worldview, but also strategically to spread their messages on social media and traditional media. This strategy comes as no surprise, since populist actors, as Mazzoleni and Bracciale (2018, p. 3) put it, "have everywhere constantly relied on the visibility and the ensuing popularity assured by the coverage, both critical and supportive, of mainstream and popular media." It should be noted that social media is used by populist actors to "bypass the forceful power of mass media" (Mazzoleni \& Bracciale, 2018, p. 3), as well as to influence their agenda (Casero-Ripollés, Sintes-Olivella, \& Franch, 2017, p. 689).

The majority of the studies in the field of social media and populism deal with the communication of well-known populist politicians and political parties and 
in particular with right-wing populist actors (Arzheimer, 2015; Engesser, Ernst, Esser, \& Büchel, 2016; Mazzoleni \& Bracciale, 2018; Stier, Posch, Bleier, \& Strohmaier, 2017). This focus is quite reasonable since the usage of populist communication strategies is most obvious in the context of professional politicians who are known for their populist attitude, such as Matteo Salvini from the rightist Italian party Lega Nord (Mazzoleni \& Bracciale, 2018, p. 4). Right-wing politicians are particularly successful on social media, as several authors, including Bobba (2019) with regard to Italy, demonstrates. Ernst, Engesser, Büchel, Blassnig, and Esser (2017, p. 1356), have furthermore shown that "politicians belonging to right parties use populist communication strategies most frequently" (see also Jagers \& Walgraave, 2007). Besides research on "'elite' populist actors" (Krämer, 2017, p. 1294), only minor attention has been given to "non-elite actors" (Krämer, 2017, p. 1294). Yet, most of the social media users are just average citizens. To the best of the authors' knowledge, so far only Hameleers and Schmuck (2017, p. 1425) distinguish "between populist politicians and ordinary citizens as communicators of populist messages" in an empirical article. The authors (Hameleers \& Schmuck, 2017, p. 1428) examine the effects of populist social media messages on the attitude of Austrians and Netherlanders in terms of blaming the government and migrants. A distinction is made between the effects of politicians' messages and messages from ordinary citizens. The authors are able to demonstrate that participants of the study who identify with the sender of a populist message, accept this message and become themselves more populist (Hameleers \& Schmuck, 2017, p. 1437). This finding is true for messages from politicians and ordinary citizens, which clearly indicates that theoretical as well as empirical knowledge on populist online activism of ordinary citizens is necessary in order to fully understand the populist penetration of today's (virtual) public sphere (Krämer, 2017, p. 1296). The need to fill this research gap has become even more urgent since the finding of Taggart (2018, p. 81), who demonstrates that a populist attitude is a potentially facilitating factor for many forms of political engagement. Anduiza, Guinjoan, and Rico $(2019$, p. 110$)$ state that it is not distrust and frustration (Meléndez \& Kaltwasser, 2019, p. 521) nor the feeling of being humiliated by the elites (Eberl \& Seubert, 2017, pp. 4-5), but it is the framing of elites as evil forces that political engagement thrives on. Engagement against the hideous elite thus may become a moral imperative. Furthermore, it is plausible that the populist idea of a political system in which the people should express their will directly exerts a positive effect on the political engagement of the bearer of this idea. Consequently, populist attitudes seem not to facilitate conventional modes of political participation, like voting, but more direct forms, "such as petition signing and the online expression of political views" (Anduiza et al., 2019 , p. 109). These findings indicate that citizens with a populist identity are particularly active in non-electoral times, which has also been shown to be true by Pirro and Portos (2020). Since Facebook, Twitter, and all the other newly emerged tools are easy-to-use, with cheap and wide-reaching information and communication technologies, they have to be seen as perfect instruments for professional and non-professional actors with a populist attitude to disseminate their political positions.

The findings presented so far indicate that the social web is far from being able to match the Habermasian criteria of communicative rationality. However, there are strong-albeit mostly theoretical-voices that speak in favour of the social web, as the new realm in which a nonhierarchical and truth-seeking discourse might take place (Loader \& Mercea, 2011; Shirky, 2011). The debate on the deliberative potential of social media has not yet been finalized. Section 5 will shed some more light on this debate by examining the Twitter discussion on migration regarding its populist permeation. Before, an insight into the research design and methodology is given.

\section{Research Design and Methodology}

\subsection{Sample}

For the analysis, almost 70,000 tweets (including metadata, such as the sender's information) on the ten most important transnational hashtags on migration were mined $(N=69,153)$. The following hashtags have been streamed, using the $\mathrm{R}$ package stream $\mathrm{R}$ which simplifies access to the Twitter application programming interface (Barberá, 2018): \#GlobalCompactMigration, \#Global Compact, \#UNMigrantCompact, \#GCM, \#Migration Compact, \#CompactOnMigration, \#Marrakesh Declaration, \#lmmigrationPact, \#MassMigration, and \#MigrationPact. The data collection phase for Twitter communication on migration lasted for two weeks from December 5th, 2018 to December 19th, 2018, covering the period before the signing conference of the GCM in Marrakesh took place and the days following the conference. Since several tweets were simply re-tweets with (exactly) the same content, only the widest-reaching doublets were kept. Thus, the sample was reduced to 14,566 tweets.

\subsection{Measuring the Populist Permeation of the Twitter Discourse}

Since populism has to be seen as a complex construct, automated methods should not be used for coding the populist content of a tweet. Thus, most empirical studies on social media and populism work with manual coding (Ernst et al., 2017). This article will follow in these (methodological) footsteps. As it is hardly feasible to code each tweet on migration, an indicator is needed to identify the level of populism in the Twitter debate on migration: the populist permeation of the 500 most popular tweets in the sub-sample of 14,566 tweets. The popularity of a tweet is measured by its number of re- 
tweets and appreciations (so-called 'favoritings'). The share of tweets that can be classified as populist will be investigated (RQ1). If it emerges that there are populist tweets, the question arises: Which populist communication strategies have been used (RQ2). In addition, an automatically conducted word pair analysis of the initial sample of almost 70,000 tweets will be applied to check the validity of the results from the manual coding procedure.

To classify populist tweets, a content analysis coding schema is used that was established by Ernst et al. (2017). See Table 1 in the Supplementary File for this article, which is available online. The schema consists of nine sub-categories of populism or rather communication strategies, which represent the three core dimensions of populism: (1) anti-elitism, (2) people-centrism and (3) restoring the sovereignty of the people. Due to the article's special interest in the occurrence of rightwing populism in the context of the migration debate on Twitter, an anti-migration dimension is added to the coding schema that consists of a modified set of the anti-elitist sub-categories. By using that schema, one or more than one sub-dimension of populism can be assigned to each tweet (unit of analysis). Since the existence of a single dimension hardly indicates that any particular tweet is populist, only those tweets that contain at least one communication strategy from at least two of the three core dimensions of populism (anti-elitism, people-centrism, restoring the sovereignty of the people) are coded as populist, furthermore, tweets need to additionally contain at least one anti-migration statement to be coded as right-wing populist. Figure 1 illustrates the coding approach. The first statement is coded as an anti-elitist statement, since it calls the Irish government treacherous (discrediting the elite) and the second statement as people-centrist, as it states a monolithic people and stresses the people's virtues. Because there are only two populist dimensions in this tweet, it is coded as a populist one, but not as a right-wing populist one due to the lack of an anti-migration statement. It should be noted that the coding was only conducted by one coder. This surely has to be seen as a methodological shortcoming.

\subsection{Bot or Not}

In the academic, as well as in the public debate the activities and the influence of fake profiles on Twitter are subject of controversial debate. This is why many academic researchers use bot detection applications. Yet, frequently used programs to detect bots have recently been criticised by Twitter for their "extremely limited approach" (Roth \& Pickles, 2020), which may cause "false negatives (i.e., bots being classified as humans) and false positives (i.e., humans being classified as bots)," as Rauchfleisch and Kaiser (2020, p. 1) put it. With regard to inauthentic content from human Twitter users (e.g., state-driven trolls), the situation becomes even more complex. Yet, there is recent research indicating that "that their effect on social platforms was minor" (Zannettou et al., 2019, p. 218). Interestingly, journalists, who are very important disseminators of Twitter content, seem unfamiliar with 'fact-checking and verification services' - despite the controversies on the malicious use of automation on Twitter and the alleged influence of trolls. The same seems to be true for the public (Varol \& Uluturk, 2020, p. 98). It would seem to follow that neither the majority of professional opinion-makers nor its recipients distinguish between authentic and inauthentic content on Twitter. This comes as no surprise since it is actually not that easy to distinguish between authentic and inauthentic activity. Taking all the above arguments into account, an examination of tweets regarding their authenticity (was this particular tweet created by a bot, a troll or an authentic user?) is not conducted. However, it needs to be stressed that the empirical results of this study potentially might have been influenced by inauthentic content. This has to be taken into account when reading the following section.

\section{Empirical Findings: The Populist Permeation of the Twitter Dialogue on Migration}

First of all, it is interesting to note that all of the 500 widest-reaching tweets are re-tweets. Most of them refer to professional political actors. Yet, only 12 tweets match the applied operationalization of a populist tweet (2.40 percent) and only two the conceptualization of right-wing populism. Additionally, it should be noted that their reach has to be considered as rather low since only one of those tweets initiated more than 1,000 retweets and favoritings (see Table 2 and Table 3 in the Supplementary File). Nevertheless, it is interesting to note that 10 of those 14 (right-wing) populist tweets contain at least one anti-elitist and one people-centrist statement. This indicates that anti-elitism and people-

$\begin{array}{ll} & \text { Gearóid Murphy @ gearoidmurphy_ } \cdot \text { 7. Dez. } 2018 \\ \text { statement } 1 & \text { Treasonous Irish Government about to sign \#UNMigrationPact effectively } \\ & \text { making migration a human right. Corporate media on blackout mode. But } \\ \text { statement 2 } & \begin{array}{l}\text { the fools, the fools, the fools.. In spite of relentless gaslighting, bribery and } \\ \text { intimidation - Irish people are waking up fast. }\end{array}\end{array}$

Figure 1. Coding of a tweet: Example for the coding approach. Source: Murphy (2018). 
centrism is the most frequently used populist combination in the discourse on migration. Furthermore, we found both dimensions occur most frequently (Figure 2), yet, in most cases not combined. This finding supports the classical conceptualization of populism, in which antielitism and people-centrism have been seen as the two very basic elements of populism (Canovan, 1999; Laclau, 1979). By taking a closer look at the anti-elitist dimension, one finds that blaming and discrediting elites occur the most. Regarding the people-centrist dimension, stating the existence of a monolithic people has to be seen as the most prominent communication strategy.

A prominent example of a populist tweet is one created by the leader of the UK Independence Party in Wales stating that "any politician who willingly signs up to the \#MigrationCompact has betrayed their people" (Shelly, 2018). This tweet contains the two core elements of populism: anti-elitism (all politicians that sign the GCM are fraudsters) and people-centrism (the people will be betrayed). The description of elites as being treasonous to the people, who are described as sharing common feelings, desires and opinions on the GCM seems to be a popular strategy of populist actors in the realm of the Twitter debate on the GCM since this accusation can be found in several other populist tweets. There is talk about, e.g., the "treasonous...Government" (O'Neill, 2018), government acting "is against its own people" (Martin, 2018), "High Treason against" (Walters, 2018) the people, betrayal of "our children" (Sabhat28, 2018), or the people who are united by their rejection of the GCM (see Table 2 and Table 3 in the Supplementary File).

Furthermore, some Twitter users allege "a conspiracy of silence" (Gormally, 2018) of the "corporate media" (O'Neill, 2018) and politics and as being "on blackout mode" (O'Neill, 2018) with regard to the GCM. It is alleged that "the media and political establishment so far have refused to inform or consult with the...people" (Gormally, 2018). In addition, it is alleged that the GCM prohibits criticism of migration ("under this pact, stories like this will be banned"; Shields, 2018). These findings support the thesis of Canovan $(1999$, p. 3), who states that populism not only challenges political actors but also those actors, who allegedly disseminate elite values against the will and the basic interests of the people. Moreover, toying with the human fear of the unknown and the stranger is detected. One author writes that by signing the GCM "\#ISIS terrorists" (Walters, 2018) will be imported and another that it "could extinguish" (Tenacious, 2018) the identity of his country. The GCM is also described as a possible threat to the sovereignty of the people and as a compact that "dictate(s) immigration policy and removes sovereignty" (Greine, 2018), as well as a contract that gives "control of our borders and sovereignty to a corrupt unelected bureaucracy" (Orchard, 2018). The two right-wing populist tweets contain as additional elements anti-migration strategies (see Table 3 in the Supplementary File), namely the (implicit) description of migrants as "non-citizens" (Shields, 2018), welfare recipients and "terrorists" (Walters, 2018). Those

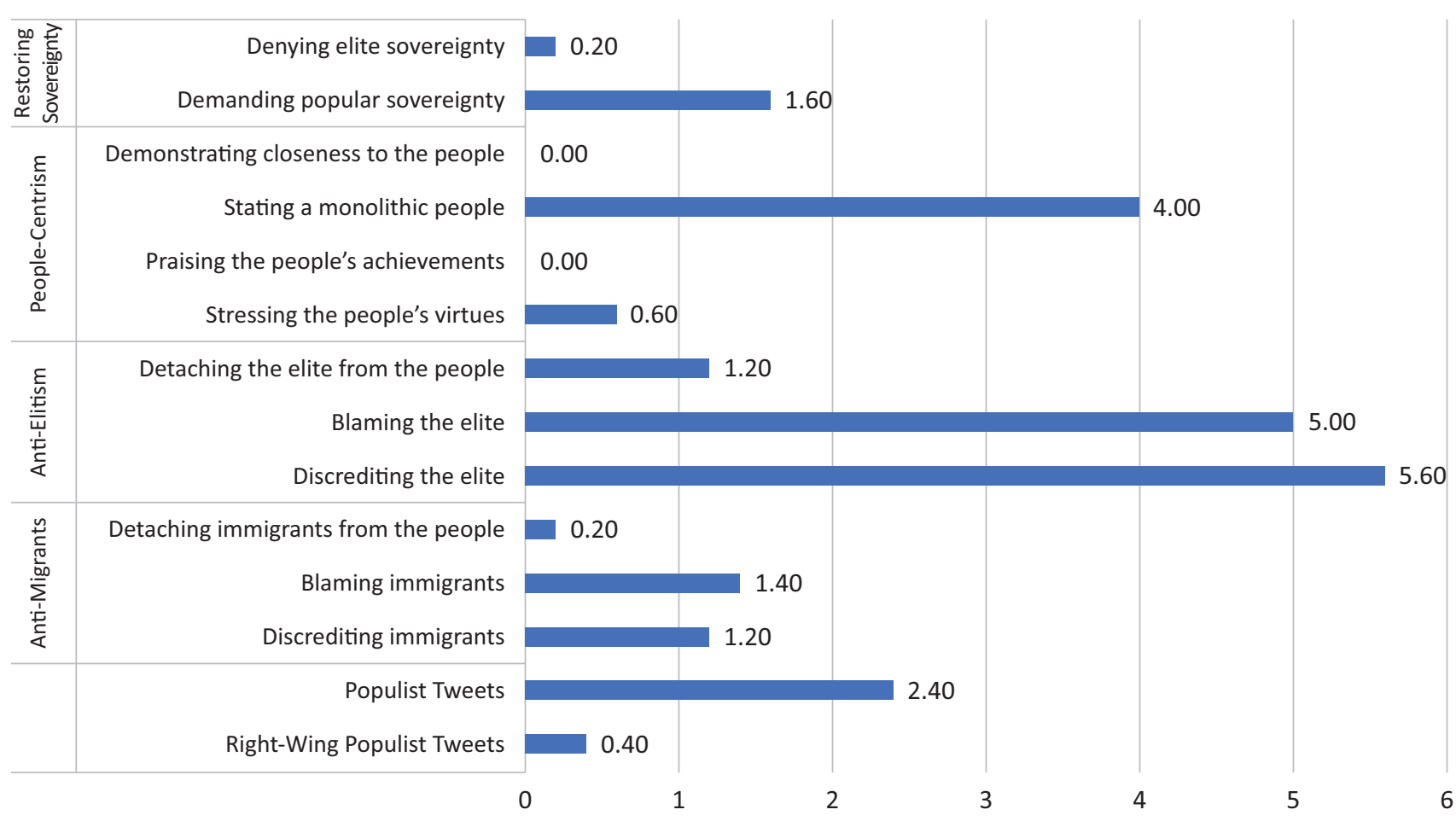

Figure 2. Share of all (right-wing) populist tweets and all populist communication strategies among the widest-reaching tweets ( $N=500$ tweets). 
tweets indicate that there has indeed been a populist "campaign to save the country" (Canovan, 1999, p. 6).

Yet, it needs to be stressed (again) that not many tweets were found that contained at least two populist statements representing at least two different core dimensions of populism and almost none that additionally contained at least one anti-migration statementas already mentioned. However, it is interesting to note that 13.6 percent of the tweets analysed contain at least one populist sub-category and thereby a soft form of populism, as Mazzoleni and Bracciale $(2018$, p. 7) have called social media messages with "only one populist reference." This finding is in line with the finding of Ernst et al. (2017) who found slightly more than ten percent of their social media sample contained at least one populist reference.

The results of an automated analysis of the most frequently used word-pairs in the overall sample of almost 70,000 tweets support the result of the manual examination of the sub-sample ( $N=14,566$ tweets), because no word-pair was found that would have indicated that the discourse on migration was strongly permeated by populist narratives (see Table 4 in the Supplementary File). Yet, the results indicate that the Twitter discourse on migration during the signing conference was predominantly critical against the compact, since the fifth, sixth, and seventh-most frequently used word pairs refer to a video of demonstrators against the GCM in Brusselsone of the most popular tweets in the sample (Figure 3). Furthermore, the word pair 'protest rt' occurs among the top 10 word-pairs, indicating that tweets showing protest against the GCM occur very frequently ( $r$ means 're-tweet').
Examining the Twitter profiles of the senders of the 12 populists' tweets, it seems like those users are ordinary citizens (see Tables 2 and 3 in the Supplementary File). Among other indicators (no obvious affiliation to a certain political party; no self-description as being a politician etc.) the moderate number of followers (range: 144-6,565) supports the assumption that we are indeed referring to normal citizens and not famous people or well-known professional politicians. This observation is interesting, as it indicates that ordinary citizens can be quite influential on social media. Moreover, it shows that populist communication in the digital sphere needs not to be the exclusive domain of professional politicians or political organizations, but also the matter of ordinary citizens. Yet, one has to recognize that those ordinary citizens did not create their own content but retweeted that of other users. Interestingly, 5 of the 12 populist tweets were initially created by ordinary citizens. Furthermore, the tweets of professional political actors, such as the leader of the UK Independence Party in Wales, were more re-tweeted and favorited than those of normal citizens. Nevertheless, it is striking to find populist tweets from ordinary citizens that were disseminated with the help of other ordinary citizens. Those non-professional actors seem to act as important disseminators for populist content and as creators of populist narratives. Almost the same is true in case of the two right-wing populist tweets. Both were created by non-elite actors with a rather low number of followers and both were re-tweets. However, the re-tweeted users were no ordinary citizens but a (former) Irish journalist and a nationalist party from Canada.

BasedPoland @BasedPoland·16. Dez. 2018

Thousands show up for a protest against the United Nations \#GlobalCompactForMigration \#GCM in \#Brussels today.

The protest started at Schuman square \& later continued outside the HQ of the \#EuropeanParliament \& \#EuropeanCouncil.

Europeans have had enough of mass-immigration!

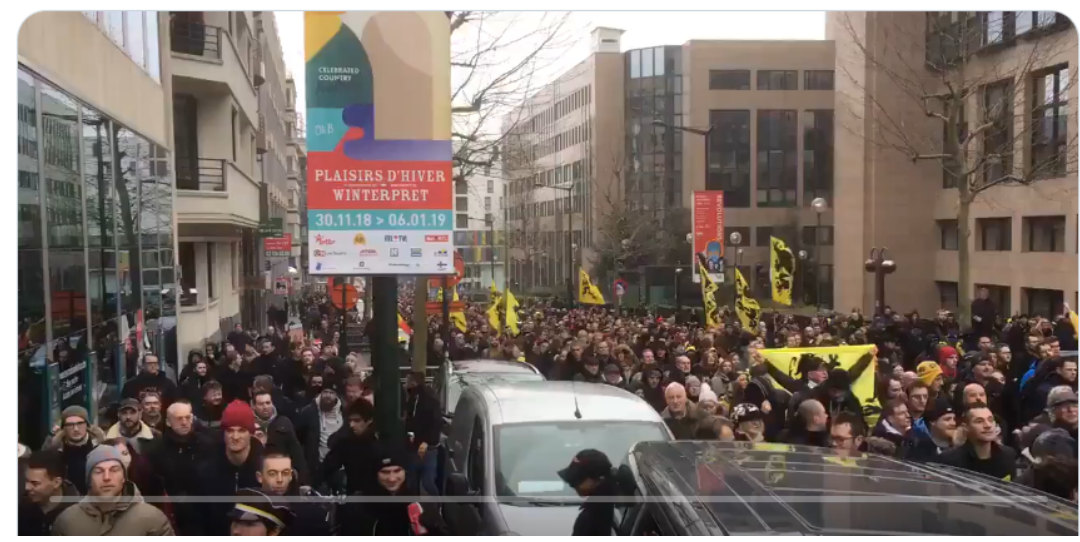

Figure 3. Tweet with a video of demonstrators against the GCM. Source: BasedPoland (2018). 


\section{Conclusion}

In light of the aforementioned results, the remarkable and maybe surprising result is that the Twitter discourse on migration during the period of the signing conference on the GCM has not been dominated by (right-wing) populist narratives (RQ1). Although the debate on the GCM must be seen as predominately critical against the compact in general and against migration in particular, only very few (right-wing) populist tweets were found among the most popular tweets. Yet, it is interesting to note that most of the few (right-wing) populist tweets contain anti-elitist and people-centrist statements. It seems like those dimensions are, as previous work has already indicated, the most important ones in the realm of online populist communication (RQ2). The populist (re-)tweets identified were published by ordinary citizens and not by professional politicians. Furthermore, half of the populist tweets were initially created by other ordinary citizens. Yet, one-third of the populist tweets identified were originally created by professional political actors, indicating that ordinary citizens also seem to be very important disseminators of (right-wing) populist content created by professional politicians.

Finding populist content among the widest-reaching tweets demonstrates that while the populist penetration of the discourse on migration on social media might be less strong than expected, professional, as well as non-professional populist actors might influence the attitudes of a large number of people. We have to keep in mind that tweets might create populist attitudes among their recipients (Hameleers \& Schmuck, 2017, p. 1437). Moreover, journalists looking for a good story (Chadwick, 2017) might have used those few (right-wing) populist tweets to indicate a larger critical assessment of the GCM on social media. Thus, even when the empirical results reveal only a few populist contents and even when some of this content might be created by bots or trolls, this content might have been very influential. Interestingly, the findings indicate that populist online activism goes beyond the organized groups, movements, etc., of civil society. We might face a new type of political activism making use of the social web to spread (right-wing) populist narratives that do not match the assumptions being made in the concept of the public sphere in terms of an alleged civil character. It follows that social media indeed seems to provide free access for the citizenship and thus the opportunity to participate in political issues, such as in the case of the GCM. However, such kind of populist participation can hardly be seen as enriching the public sphere, but rather as an element of its corruption. This finding is in line with previous empirical work on the role of social media for the concept of the public sphere (Kruse et al., 2018, p. 82).

Yet, it needs to be emphasized that the presented findings are limited to Twitter. Against the empirical data presented by Ernst et al. (2017, p. 1357), one might assume that the migration dialogue on Facebook is penetrated to a greater degree by populist statements. Unfortunately (at least from a scientific point of view), Facebook has shut down most parts of its application programming interface. Thus, it is virtually impossible to determine whether the presented findings are also true for the migration discourse on Facebook. One option would be the (re-)examination of already queried Facebook data under the aspects of this article. Furthermore, there is a huge research gap in the usage of other social media tools than Twitter and Facebook by populist actors, such as Telegram, WhatsApp, and Instagram. In particular, Telegram and WhatsApp seem to be interesting cases, as it has already been shown that those tools were extensively (mis)used by right-wing actors (Davis \& Straubhaar, 2020; Urman \& Katz, 2020).

\section{Acknowledgments}

I would like to thank Professor Marianne Kneuer for her valuable and constructive suggestions during the planning and development of this research work. I acknowledge financial support by Stiftung Universität Hildesheim.

\section{Conflict of Interests}

The author declares no conflict of interests.

\section{Supplementary Material}

Supplementary material for this article is available online in the format provided by the author (unedited).

\section{References}

Anduiza, E., Guinjoan, M., \& Rico, G. (2019). Populism, participation, and political equality. European Political Science Review, 11(1), 109-124. https://doi.org/ $10.1017 / \mathrm{S} 1755773918000243$

Araujo, T., \& van der Meer, T. G. (2020). News values on social media: Exploring what drives peaks in user activity about organizations on Twitter. Journalism, 50(5). https://doi.org/10.1177/1464884918809299

Arzheimer, K. (2015). The AfD's Facebook wall: A new hub for far-right mobilisation in Germany? Kai Arzheimer. Retrieved from http://www.kai-arzheimer.com/ german-right-wing-internet.pdf

Barberá, P. (2018). Access to Twitter streaming API via R. CRAN. CRAN. Retrieved from https://cran.r-project. org/web/packages

Bartlett, J. (2014). Populism, social media and democratic strain. In C. Sandelind (Ed.), European populism and winning the immigration debate (1st ed., pp. 99-114). Stockholm: Fores.

BasedPoland [BasedPoland]. (2018, December 16). Thousands show up for a protest against the United Nations \#GlobalCompactForMigration \#GCM in \#Brussels today. The protest started at Schuman 
square \& later continued outside the $\mathrm{HQ}$ of the \#EuropeanParliament \& \#EuropeanCouncil. Europeans have had enough of mass-migration! [Tweet]. Retrieved from https://twitter.com/basedpoland/ status/1074348661663035393

Bloom, T. (2019). When migration policy isn't about migration: Considerations for implementation of the Global Compact for Migration. Ethics \& International Affairs, 33(4), 481-497. https://doi.org/ $10.1017 /$ S0892679419000443

Bobba, G. (2019). Social media populism: Features and 'likeability' of Lega Nord communication on Facebook. European Political Science, 18(1), 11-23. https://doi.org/10.1057/s41304-017-0141-8

Canovan, M. (1999). Trust the people! Populism and the two faces of democracy. Political Studies, 47(1), 2-16. https://doi.org/10.1111/1467-9248.00184

Casero-Ripollés, A., Sintes-Olivella, M., \& Franch, P. (2017). The populist political communication style in action: Podemos's issues and functions on Twitter during the 2016 Spanish general election. American Behavioral Scientist. Advance online publication. https://doi.org/10.1177/0002764217707624

Castells, M. (2009). Communication power. Oxford: Oxford University Press.

Chadwick, A. (2017). The hybrid media system: Politics and power (2nd ed.). New York, NY: Oxford University Press.

Davis, S., \& Straubhaar, J. (2020). Producing antipetismo: Media activism and the rise of the radical, nationalist right in contemporary Brazil. International Communication Gazette, 82(1), 82-100. https://doi.org/ $10.1177 / 1748048519880731$

Downey, J., \& Fenton, N. (2003). New media, counter publicity and the public sphere. New Media \& Society, 5(2), 185-202. https://doi.org/10.1177/1461 444803005002003

Eberl, J.-M., Meltzer, C. E., Heidenreich, T., Herrero, B., Theorin, N., Lind, F., . . . Strömbäck, J. (2018). The European media discourse on immigration and its effects: A literature review. Annals of the International Communication Association, 42(3), 207-223. https:// doi.org/10.1080/23808985.2018.1497452

Eberl, O., \& Seubert, S. (2017). European political citizenship 2030: Postdemocracy with populist activism or an integrated political and social citizenship? Policy scenarios and recommendations from BEUcitizen, a research project on the barriers to realise and exercise citizenship rights by European Union citizens. BEUcitizen. Retrieved from https://zenodo.org/ record/344806/files/2017-01-12\%20POLICY\%20 BRIEF\%20WP2\%20Eberl\%20Seubert\%20FINAL.pdf? download $=1$

Eilders, C. (2006). News factors and news decisions: Theoretical and methodological advances in Germany. Communications, 31(1). https://doi.org/ 10.1515/COMMUN.2006.002

Engesser, S., Ernst, N., Esser, F., \& Büchel, F. (2016). Pop- ulism and social media: How politicians spread a fragmented ideology. Information, Communication \& Society, 20(8), 1109-1126. https://doi.org/10.1080/ 1369118X.2016.1207697

Ernst, N., Engesser, S., Büchel, F., Blassnig, S., \& Esser, F. (2017). Extreme parties and populism: An analysis of Facebook and Twitter across six countries. Information, Communication \& Society, 20(9), 1347-1364. https://doi.org/10.1080/1369118X.2017.1329333

Fuchs, C. (2017). Donald Trump: A critical theoryperspective on authoritarian capitalism. TripleC: Communication, Capitalism \& Critique, 15(1), 1-72. https://doi.org/10.31269/triplec.v15i1.835

Galtung, J., \& Ruge, M. H. (1965). The structure of foreign news. Journal of Peace Research, 2(1), 64-90. https://doi.org/10.1177/002234336500200104

Gormally, A. [GormallyAndrew]. (2018, December 5). RT @IrexitFreedom: There has been a conspiracy of silence surrounding the \#UNMigrationPact in Ireland. The media and political establishment so far have refused to inform or consult with the Irish people on this pact. We will protest on Thursday [Tweet]. Retrieved from https://twitter.com/GormallyAndrew/ status/1070298220339748864

Greine, J. [GMAN31982]. (2018, December 7). RT @LVNancy: \#Canada is waking up too. The \#MigrationPact essentially allows UN to dictate immigration policy and removes sovereignty of a [Tweet]. Retrieved from https://twitter.com/GMAN31982/ status/1071043926499373056

Guild, E., Basaran, T., \& Allinson, K. (2019). From zero to hero? An analysis of the human rights protections within the Global Compact for Safe, Orderly and Regular Migration (GCM). International Migration, 57(6), 43-59. https://doi.org/10.1111/imig.12609

Habermas, J. (1984). The theory of communicative action: Reason and the rationalization of society (Vol. 1). Boston, MA: Beacon Press.

Habermas, J. (1989). The structural transformation of the public sphere. Cambridge: MIT Press, 85, 85-92.

Hameleers, M., \& Schmuck, D. (2017). It's us against them: A comparative experiment on the effects of populist messages communicated via social media. Information, Communication \& Society, 20(9), 1425-1444. https://doi.org/10.1080/2017.1328523

Heidenreich, T., Eberl, J.-M., Lind, F., \& Boomgaarden, H. (2020). Political migration discourses on social media: A comparative perspective on visibility and sentiment across political Facebook accounts in Europe. Journal of Ethnic and Migration Studies, 46(7), 1261-1280. https://doi.org/10.1080/ 1369183X.2019.1665990

Hill, K. A., \& Hughes, J. E. (1998). Cyberpolitics: Citizen activism in the age of the Internet: People, passions, and power. Lanham, MD: Rowman \& Littlefield.

International Organisation for Migration. (2019). Global Compact for Migration. IOM. Retrieved from https:// www.iom.int/global-compact-migration 
Jagers, J., \& Walgraave, S. (2007). Populism as political communication style: An empirical study of political parties' discourse in Belgium. European Journal of Political Research, 46(3), 319-345. https://doi.org/ 10.1111/j.1475-6765.2006.00690.x

Krämer, B. (2017). Populist online practices: The function of the Internet in right-wing populism. Information, Communication \& Society, 20(9), 1293-1309. https://doi.org/10.1080/1369118X.2017.1328520

Kruse, L. M., Norris, D. R., \& Flinchum, J. R. (2018). Social media as a public sphere? Politics on social media. The Sociological Quarterly, 59(1), 62-84. https:// doi.org/10.1080/00380253.2017.1383143

Laclau, E. (1979). Politics and ideology in Marxist theory: Capitalism, fascism, populism (2nd ed.). London: NLB.

Lippmann, W. (1922). Public opinion (1st ed.). New Brunswick, NJ: Transaction Publishers.

Loader, B. D., \& Mercea, D. (2011). Networking democracy? Information, Communication \& Society, 14(6), 757-769. https://doi.org/10.1080/1369118X.2011. 592648

Lutz, P. (2018). Variation in policy success: Radical right populism and migration policy. West European Politics, 51(2), 517-544. https://doi.org/10.1080/ 01402382.2018 .1504509

Martin, J. [jamohio9719]. (2018, December 11). RT @DrCollins10: Our government is against its own people. Why? They are about to sign the \#UNMigrationPact which will bring in thousands [Tweet]. Retrieved from https://twitter.com/ jamohio9719/status/1072568087948464132

Mazzoleni, G., \& Bracciale, R. (2018). Socially mediated populism: The communicative strategies of political leaders on Facebook. Palgrave Communications, 4(1). https://doi.org/10.1057/s41599-018-0104-x

Meléndez, C., \& Kaltwasser, C. R. (2019). Political identities: The missing link in the study of populism. Party Politics, 25(4), 520-533. https://doi.org/ $10.1177 / 1354068817741287$

Mudde, C. (2004). The populist zeitgeist. Government and Opposition, 39(4), 542-563. https://doi.org/ 10.1111/j.1477-7053.2004.00135.x

Murphy, G. [gearoidmurphy_]. (2018, December 7). Treasonous Irish Government about to sign \#UNMigrationPact effectively making migration a human right. Corporate media on blackout mode. But the fools, the fools, the fools. In spite of relentless gaslighting, bribery and intimidation-Irish people are waking up fast [Tweet]. Retrieved from https:// twitter.com/gearoidmurphy_/status/107110717471 6325888

Müller, J.-W. (2016). What is populism? Philadelphia, PA: University of Pennsylvania Press.

O'Neill, A. [artoneill1523]. (2018, December 19). RT @gearoidmurphy_: Treasonous Irish Government about to sign \#UNMigrationPact effectively making migration a human right. Corporate media on black- out mode. But the fools, the fools, the fools. In spite of relentless gaslighting, bribery and intimidationIrish people are waking up fast [Tweet]. Retrieved from https://twitter.com/artoneill1523/status/1075 189096237150208

Orchard, E. [EduardoOrchard]. (2018, December 11). RT @gemmaod1: Belgian government on brink of collapse over \#UN \#MigrationPact \#GlobalCompact. Not one party in Dail or media cares about giving control of our borders and sovereignty to a corrupt unelected bureaucracy. I'm coming up on @RichieAllenShow at $6.15 \mathrm{pm}$ [Tweet]. Retrieved from https://twitter.com/EduardoOrchard/status/ 1072421661788512256

Östgaard, E. (1965). Factors Influencing the flow of news. Journal of Peace Research, 2(1), 39-63. https://doi. org/10.1177/002234336500200103

Papacharissi, Z. (2009). The virtual sphere 2.0: The Internet, the public sphere and beyond. In A. Chadwick \& P. N. Howard (Eds.), Routledge international handbooks: Routledge handbook of Internet politics (pp. 230-245). London and New York, NY: Routledge.

Pirro, A. L. P., \& Portos, M. (2020). Populism between voting and non-electoral participation. West European Politics. https://doi.org/10.1080/01402382. 2020.1739451

Privitera, W. (2018). The public sphere and the populist challenge. Sociology (Vol. 3). Milan: Mimesis International.

Rauchfleisch, A., \& Kaiser, J. (2020). The false positive problem of automatic bot detection in social science research. SSRN Electronic Journal. Advance online publication. https://doi.org/10.2139/ssrn.3565233

Rooduijn, M. (2014). The mesmerising message: The diffusion of populism in public debates in western European media. Political Studies, 62(4), 726-744. https://doi.org/10.1111/1467-9248.12074

Roth, Y., \& Pickles, N. (2020). Bot or not? The facts about platform manipulation on Twitter. Twitter Blog. Retrieved from https://blog.Twitter.com/en_ us/topics/company/2020/bot-or-not.html

Sabhat28 [Sabhat28]. (2018, December 9). RT @Genldentitylrl: \#UNMigrationPact - \#ATraitors Receipt In Marrakesh @CampaignforLeo will eat a UN lunch. After that he will get a piece of paper.to sign away our birthright, our island nation. When our children ask of their betrayal, his name will be told [Tweet]. Retrieved from https://twitter.com/ Sabhat28/status/1071699637176860672

Shelly [reecyb2]. (2018, December 19). RT @NeilUKIP: Any politician who willingly signs up to the \#MigrationCompact has betrayed their people. Mr. Michel is right to offer his resignation [Tweet]. Retrieved from https://twitter.com/reecyb2/status/ 1075753039196246018

Shields, D. [DonalShields]. (2018, December 11). RT @gemmaod1: Varadkar has signed \#Ireland up to the corrupt \#MigrationPact without any public consulta- 
tion, paving the way for open borders and mass immigration. New stats show $63 \%$ of non-citizens in US collect welfare. Under this pact, stories like this will be banned [Tweet]. Retrieved from https://twitter. com/DonalShields/status/1072607605636456450

Shirky, C. (2011). The political power of social media: Technology, the public sphere, and political change. Foreign Affairs, 90(1), 28-41.

Sorensen, L. (2018). Populist communication in the new media environment: A cross-regional comparative perspective. Palgrave Communications, 4(1). https:// doi.org/10.1057/s41599-018-0101-0

Stier, S., Posch, L., Bleier, A., \& Strohmaier, M. (2017). When populists become popular: Comparing Facebook use by the right-wing movement Pegida and German political parties. Information, Communication \& Society, 20(9), 1365-1388. https://doi.org/ 10.1080/1369118X.2017.1328519

Taggart, P. (2018). Populism and 'unpolitics.' In G. Fitzi, J. Mackert, \& B. S. Turner (Eds.), Routledge advances in sociology: Populism and the crisis of democracy (pp. 79-88). London and New York, NY: Routledge Taylor \& Francis Group.

Tenacious, T. [tenaciousT0286]. (2018, December 15). RT @Chris_A10_USA: \#Canada 's PM \#Trudeau supports the \#UN \#MigrationPact that could extinguish \#Canadian \#identity \#TrudeauMustGo \#NoOpenB [Tweet]. Retrieved from https://twitter.com/ tenaciousT0286/status/1071476692529635328

United Nations. (2018). Statement by Louise Arbour, Special Representative of the Secretary-General for International Migration. New York, NY: United Nations. Retrieved from https://www.un.org/en/ conf/migration/assets/pdf/GCM-Statements/ closingremarksarbour.pdf

United Nations. (2020). Global Compact for Migration: Intergovernmental conference, 2018 Marrakech. United Nations. Retrieved from https:// www.un.org/en/conf/migration/faqs.shtml

United Nations Human Rights. (2016). New York declaration. New York, NY: United Nations. Retrieved from https://www.ohchr.org/EN/Issues/Migration/ Pages/NewYorkDeclaration.aspx

Urman, A., \& Katz, S. (2020). What they do in the shadows: Examining the far-right networks on Telegram. Information, Communication \& Society. Advance online publication. https://doi.org/10.1080/1369118X. 2020.1803946

US Mission to the United Nations. (2018). National statement of the United States of America on the adoption of the Global Compact for Safe, Orderly, and Regular Migration. UN Mission to the United Nations. Retrieved from https://usun.usmission.gov/nationalstatement-of-the-united-states-of-america-on-theadoption-of-the-global-compact-for-safe-orderlyand-regular-migration

van Dijck, J., \& Poell, T. (2013). Understanding social media logic. Media and Communication, 1(1), 2-14. https://doi.org/10.12924/mac2013.01010002

Varol, O., \& Uluturk, I. (2020). Journalists on Twitter: Selfbranding, audiences, and involvement of bots. Journal of Computational Social Science, 3(1), 83-101. https://doi.org/10.1007/s42001-019-00056-6

Walters, L. [LanieWalters]. (2018, December 6). RT @central_cap: He treats \#Taxpayer funds like his trust fund. He treats \#Canada as a country owned by him. \#MigrationCompact He puts \#Canadian citizens in danger by importing \#ISIS terrorists whom CANNOT BE REHABILITATED. Off to \#GITMO for High Treason... [Tweet]. Retrieved from https://twitter.com/ LanieWalters/status/1070723388350451714

Zannettou, S., Caulfield, T., Cristofaro, E. d., Sirivianos, M., Stringhini, G., \& Blackburn, J. (2019). Disinformation warfare: Understanding state-sponsored trolls on Twitter and their influence on the web. In L. Liu, R. White, S. Amer-Yahia, \& M. Madian (Eds.), The web conference 2019: Companion of the World Wide Web Conference WWW 2019 (pp. 218-226). Geneva: International World Wide Web Conferences Steering Committee. https://doi.org/10.1145/ 3308560.3316495

\section{About the Author}

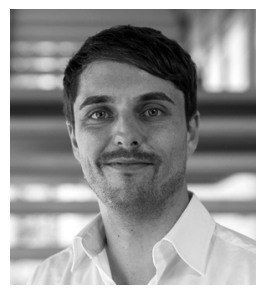

Mario Datts studied Political Science in Hanover and Berlin and finished his studies with a thesis on the pirate party. He then obtained his Doctorate at the University of Düsseldorf with his doctoral thesis on the usage of social media by political parties. Since 2018, Mario Datts has been working as a Postdoctoral Research Associate at the University of Hildesheim under the thematic priority 'politics and Internet.' 